\title{
Polski emigracyjny ruch wydawniczo- -księgarski w Lipsku w latach 1830-1918
}

\begin{abstract}
STreszCzenie. Artykuł jest próbą zebrania i usystematyzowania materiałów na temat polskiego emigracyjnego ruchu wydawniczo-księgarskiego w Lipsku. Zasięg chronologiczny obejmuje lata 1830-1918, bezpośrednio przed powstaniem listopadowym i związaną z nim Wielką Emigracją aż do odzyskania przez Polskę niepodległości w 1918 roku.
\end{abstract}

SŁowA KLuczowe: Wielka Emigracja, ruch wydawniczo-księgarski, Lipsk, Jan Nepomucen Bobrowicz, Erazm Łukasz Kasprowicz, Paweł Rhode.

„Wyszliśmy na wygnanie, więc i książki polskie, towarzysze losów, znalazły się między nami i w rozstrzeleniu pozostają tak jak umysły nasze..."1

Dzieje Polski ułożyły się w łańcuch tragicznych wydarzeń oraz procesów społecznych, politycznych i ekonomicznych, sprawiając, że na przestrzeni wieków poza granicami kraju znalazły się wielomilionowe rzesze Polaków. Schronienia przed represjami zmuszeni byli szukać za granicą obywatele najlepsi, szczerze oddani i najbardziej zaangażowani w odzyskanie niepodległości ${ }^{2}$. Na tułaczkę rzuceni zostali arianie, przywódcy Sejmu Czteroletniego, uczestnicy powstań narodowowyzwoleńczych, działacze społeczni, rewolucyjni i państwowi, wybitni uczeni, literaci i artyści. Emigrowała biedota, dla której zabrakło pracy, emigrowali wreszcie ci, którzy wśród obcych widzieli dla siebie większe szanse rozwoju naukowego lub artystycznego.

${ }^{1}$ K. Sienkiewicz, „Kronika Emigracji Polskiej” 1836.

2 A. Kłossowski, Rola ksiegarstwa i drukarstwa polskiego na obczyźnie. Stan i problematyka badań, „Studia o Książce” 1970, t. 1, s. 133-158. 
Począwszy od 1831 roku, z inicjatywy najbardziej światłych i ofiarnych rodaków tworzono w różnych państwach placówki naukowe, literackie i oświatowe, których zadaniem były między innymi ochrona niszczonych w Polsce skarbów narodowych oraz przeciwdziałanie wynaradawianiu szerokich rzesz emigrantów.

Emigrację polską XIX i XX wieku tworzyli ludzie o rozwiniętej świadomości społecznej. Za granicą szukali schronienia przed represjami i możliwości swobodnego wygłaszania swych przekonań. Swoistą grupę stanowiła młodzież polska wcielana do wojsk państw zaborczych, wreszcie fala licznego wychodźstwa zarobkowego, które nasiliło się w latach 80. XIX stulecia i w okresie międzywojennym. W XIX i XX wieku stale bądź czasowo działali na dobrowolnej lub przymusowej emigracji literaci, uczeni, politycy i wojskowi tej miary co Józef Bohdan Zaleski, Maurycy Mochnacki, Józef Ignacy Kraszewski, Władysław Mickiewicz, Benedykt Dybowski, Julian Tuwim.

Biorąc pod uwagę proweniencję książek pojawiających się w społeczeństwie polonijnym, można wyróżnić:

- książki wywiezione z Polski przez emigrantów,

- książki stale napływające z kraju do placówek emigracyjnych,

- druki wydawane za granicą staraniem samego wychodźstwa na własny użytek lub z myślą o kolportażu ich w kraju ${ }^{3}$.

Na takie trzy grupy badacze podzielili książki emigracyjne. Interesuje mnie przede wszystkim trzecia grupa, a dokładnie książki wydawane w Lipsku przez Polaków w XIX i XX wieku. Nie jest tajemnica, że od początków emigracji jej wiernym towarzyszem i sprzymierzeńcem były różnego rodzaju druki. Chlubną kartą zawodu księgarza była więc księgarska emigracja, która towarzyszyła Wielkiej Emigracji. Wśród osób aktywnie pracujących nad krzewieniem języka polskiego i polskości można wymienić Jana Nepomucena Bobrowicza czy Erazma Łukasza Kasprowicza. Współpracowali oni z takimi oficynami niemieckimi jak Oficyna Breitkopfa oraz Drukarnia Brockhausa. Emigranci oprócz współpracy z obcymi drukarniami zakładali własne drukarnie i księgarnie.

$\mathrm{Na}$ wymienienie zasługują również księgarze w innych krajach europejskich i światowych. Drogę przetarli przede wszystkim Eustachy Januszkiewicz, Aleksander Jełowicki oraz Stefan Dembowski - ich staraniem w 1835 roku założono spółkę pod nazwą Księgarnia i Drukarnia Polska A. Jełowickiego i Sp., która na kilka lat stała się ośrodkiem

${ }^{3}$ H. Szwejkowska, Wybrane zagadnienia z dziejów książki XIX-XX wieku, Warszawa-Wrocław 1981, s. 119-122. 
emigracyjnego ruchu umysłowego ${ }^{4}$. $Z$ biegiem czasu powstały tak znane firmy jak Księgarnia Luksemburska Władysława Mickiewicza założona w Paryżu w 1864 roku, wydawnictwo i drukarnia Władysława Dyniewicza założone w 1871 roku w Chicago czy Leona Idzikowskiego założone w 1859 roku w Kijowie 5 .

Drukowano w nich dzieła poetów i pisarzy polskich zabronionych w Polsce, liczne są również polonika w językach obcych oraz czasopisma dotyczące Polski.

W drugiej połowie XIX wieku w księgarskich relacjach z Polską przodował Lipsk. Postępująca koncentracja kapitału sprawiła, że na tym rynku książki panowały wielkie kombinaty powstałe $\mathrm{z}$ połączenia lub wchłonięcia mniejszych przedsiębiorstw wydawniczych, księgarskich czy drukarskich. Księgarze i wydawcy niedysponujący odpowiednimi środkami finansowymi i technicznymi, niemogący sobie pozwolić na szeroką akcję reklamową nie mieli żadnych szans z takimi firmami jak Johan Conrad Hinrichs, Friedrich Arnold Brockhaus, Johann Ambrosius Barth, Breitkopf und Härtel i Gotthelf Benedictus Teubner. Firmy te zdominowały wszystkie dziedziny produkcji i rozpowszechniania książki. Robiły także dobre interesy na wydawnictwach polskich i kontaktach z ziemiami polskimi ${ }^{6}$. To z Lipska przenikał do kraju postęp związany z produkcją książki, to tutaj przyjeżdżano na naukę zawodu. Wielu polskich wydawców, np. Herman Altenberg i Mieczysław Leitgeber, powierzało lipskim zakładom druk i oprawę własnych nakładów. W XIX-wiecznym Lipsku wytworzyła się dobra koniunktura do podejmowania polskich wydawnictw ${ }^{7}$.

\section{Jan Nepomucen Bobrowicz}

Jan Nepomucen Bobrowicz urodził się w maju 1805 roku w Krakowie. Pochodził ze szlacheckiego rodu wywodzącego się z Litwy. Jego rodzice, Jan oraz Marianna, interesowali się muzyka, naturalne więc było ich marzenie, by syn również kształcił się w tym kierunku. Tak też się stało. Jan Nepomucen wchodził w skład członków Towarzystwa Przyjaciół Muzyki, a od roku 1829 brał udział w koncertach w miastach zarówno polskich, jak i europejskich.

4 A. Kłossowski, Rola księgarstwa i drukarstwa polskiego..., s. 143.

${ }^{5}$ Ibidem, s. 144.

${ }^{6}$ A. Kłossowski, Na obczyźnie. Ludzie polskiej książki, Wrocław 1984, s. 108-109.

7 A. Kłossowski, Polscy ksieggarze i wydawcy w Lipsku w XIX w. Paweł Rhode i jego poprzednicy, „Roczniki Biblioteczne” 1976, z. 1-2, s. 155-157. 
Kariera zawodowa Bobrowicza była związana jednak nie z muzyka, ale z działalnością edytorską i księgarską.

Bezspornym faktem jest udział i wielkie zaangażowanie Bobrowicza w powstaniu listopadowym. W chwili wybuchu rewolucji porzucił pracę w sekretariacie Senatu Krakowa; jako podporucznik artylerii konnej w powstaniu 1831 roku otrzymał krzyż Virtuti Militari ${ }^{9}$.

Po upadku rewolucji Bobrowicz wraz z innymi żołnierzami udał się na emigrację. Celem była Francja, Lipsk jedynie pierwszym etapem tułaczki. W styczniu 1832 roku Bobrowicz z paszportem na nazwisko Jan Tamulewicz dotarł do Lipska. Zachorował i zmuszony był opuścić kompanów i pozostać w Saksonii.

Początkowo Bobrowicz brał udział w słynnych już koncertach Gewandhansu. W 1833 roku, gdy wziął udział w koncercie Klary Wieck, jego sława sięgnęła szczytów. Sam Fryderyk Liszt nazwał go „Chopinem gitary"10.

Bobrowicz trafił do lipskiego kupca o nazwisku Gotzwärg, teścia właściciela firmy Breitkopf und Härtel. Firma ta została założona w 1719 roku przez Bernharda Christopha Breitkopfa i istnieje do dziś jako wydawnictwo muzyczne pod tą samą nazwą ${ }^{11}$. Specjalizowała się przede wszystkim w branży muzycznej. W 1833 roku Bobrowicz rozpoczął współpracę z lipskim wydawnictwem, gdzie miał być odpowiedzialny za druk większości książek w języku polskim. Decyzja braci Härtlów o przyjęciu go w swoje szeregi miała zasadniczy wpływ na dalsze losy muzyka. Podejmując prace korektorskie utworów muzycznych, nie przypuszczał, że wkrótce zostanie redaktorem dużych serii wydawniczych.

Firma Breitkopf und Härtel wydała w czerwcu 1834 roku Literarische Anzeige und Einladung zur Pränumeration. Taschenbibliothek polonischer Klassiker, jednocześnie opublikowano w języku polskim Uwiadomienie literackie. Biblioteka Kieszonkowa Klasyków Polskich. Uzasadnienie podjęcia tej inicjatywy, charakterystyka serii i jej zadania zostały przedstawione w Przedmowie wydawcy zamieszczonej w pierwszym tomie Dzieł Ignacego Krasickiego. Bobrowicz, jako redaktor serii, powtarzał w przedmowie, że choć ukazało się wiele wydań literatury polskich klasyków, to jednak

${ }^{8}$ H. Batorowska, Jan Nepomucen Bobrowicz. Polski wydawca i księgarz w Saksonii w czasach Wielkiej Emigracji, Kraków 1992, s. 12-14.

9 S.P. Koczorowski, Bobrowicz Jan Nepomucen, w: Polski słownik biograficzny, t. 2, red. W. Konopczyński, Kraków 1936, s. 157-158.

${ }^{10}$ Ibidem.

${ }^{11}$ Encyklopedia wiedzy o ksiażce, red. A. Birkenmajer, B. Kocowski, J. Trzynadlowski, Wrocław 1971, s. 333. 
lipskie wydanie posiada zalety, których tamtym zabrakło. Zaliczył do nich mały format szesnastki prawie kwadratowej oraz niewielką objętość książeczek wchodzących w skład serii.

Bobrowicz podzielił „Bibliotekę Kieszonkową” na trzy oddziały. W pierwszym dziale umieszczono dzieła Ignacego Krasickiego, w drugim poezje i dzieła między innymi Adama Naruszewicza, Jana Kochanowskiego, Franciszka Karpińskiego, natomiast w trzecim - pisma, sielanki i poezje Szymona Szymonowicza, Franciszka Dionizego Kniaźnina, Jana Gawińskiego, Szymona Zimorowicza.

Masowe upowszechnienie tej literatury miały zagwarantować niskie ceny oraz poręczny format. Książki serii kosztowały średnio 2 lub 3 złote polskie, podczas gdy w kraju książki osiągały cenę 6, 7 i więcej złotych. Edycje Bobrowicza należały więc do tanich, a co za tym idzie - konkurencyjnych. Książki wychodzące w firmie Breitkopf und Härtel miały cechy druków niemieckich, wytwarzanych za pomocą nowoczesnych urządzeń typograficznych, co obniżało koszty produkcji.

Prasa krajowa ustosunkowała się do „Biblioteki Kieszonkowej” krytycznie, mimo to wydawnictwo cieszyło się niezwykłą popularnością wśród odbiorców. Nakład szybko się wyczerpał i w roku 1840 firma postanowiła przygotować drugie wydanie dziesięciotomowego oddziału pierwszej serii.

Bobrowicza nurtował $\mathrm{w}$ tym czasie projekt kontynuacji serii. Udało mu się zrealizować go dopiero w 1853 roku, gdy wydał trzy kolejne tomy „Biblioteki Kieszonkowej” we własnej firmie wydawniczej; były nimi Dzieła poetyczne Jana Pawła Woronicza ${ }^{12}$. Utwory te zakończyły ukazywanie się „Biblioteki Kieszonkowej Klasyków Polskich”, a edytor przystąpił do realizacji nowych inicjatyw wydawniczych.

Przedsięwzięciem, które przyniosło wydawcy rozgłos, było przygotowanie dziecięciotomowej edycji Herbarza polskiego Kaspra Niesieckiego. Ukazała się ona w latach 1839-1846 nakładem firmy Breitkopf und Härtel. Opinie krytyków były podzielone. Jedni domagali się ingerencji Bobrowicza w tekst oryginału, a inni sprzeciwiali się dokonywaniu jakichkolwiek poprawek. Żądano od wydawcy, aby wykazał się warsztatem naukowym i, nie poprawiając tekstu, zredagował do niego nowe przypisy. Zaatakowano również firmę Breitkopfa, pisząc, że jej właścicielom nie można wybaczyć powierzenia pracy nad Herbarzem polskim osobie niekompetentnej.

Wydawca podkreślał, że nie ma wątpliwości co do wartości tego dzieła. Stwierdził, że obiektywny czytelnik zdaje sobie sprawę z bezpodstawności

${ }^{12}$ H. Batorowska, Jan Nepomucen Bobrowicz..., s. 52-57. 
zarzutów. Bobrowicz jako redaktor spełnił wszystkie warunki, do których zobowiązał się w Prospekcie na wyjść majace Uzupetnienia do Herbarza polskiego. Wprowadził dodatki pochodzące z prac takich heraldyków jak Kuropatnicki czy Małachowski. Nie mogąc brać odpowiedziałności za autentyczność faktów w nich przytoczonych, celowo te fragmenty wydrukował mniejszą czcionką i podpisał nazwiskiem autorów.

Bobrowicz wydał u Breitkopfa również Melitelę. Noworocznik na rok 1837, której zapewnił piękny druk i luksusową oprawę; umiejętnie też dobrał ilustracje do zamieszczonych w tekście pozycji.

Bobrowicz starał się o przyznanie praw obywatelskich. Przedstawiał nowe dowody i fakty, które mogły mieć zasadniczy wpływ na przyznanie mu prawa pobytu w Niemczech. Spełniał wszystkie stawiane przez ministerstwo wymogi. I chociaż sami urzędnicy twierdzili, że nie ma najmniejszych przeszkód, aby został obywatelem Saksonii, to jednak przez 17 lat władze wydawały jedynie zezwolenia na czas określony. Nawet poślubienie obywatelki Saksonii, Fryderyki Wiktorii Petit, nie przyśpieszyło decyzji o przyjęciu Bobrowicza do grona obywateli Lipska. Formalnie został nim dopiero w czerwcu 1848 roku. Dwa tygodnie po otrzymaniu obywatelstwa Bobrowicz został właścicielem Librairie Étrangère - Polonische Verlags - und Commissions - Buchhandlung.

Firmę pod nazwą LÉ założył w lutym 1842 roku Philipp Paul von Kincel, radca dworu z Drezna. W tym też roku przeniósł się do Lipska. Zaprzyjaźniony był z rodziną Petit, rodziną żony Bobrowicza.

Już w 1842 roku Bobrowicz zarządzał wymienioną księgarnią. Wszystko wskazuje na to, że rozpoczynając działalność w Librairie Étrangère, nadal pracował dla Härtlów. W księgarni kontynuował przedsięwzięcie rozpoczęte u swoich lipskich pracodawców. Nie mógł zrezygnować z posady w firmie, ponieważ Ministerstwo Spraw Wewnętrznych odmawiało mu stałego pobytu w Lipsku. Jak wynika z korespondencji Lelewela ${ }^{13}$, Bobrowicz w latach 50. XIX wieku nadal był uzależniony od lipskich wydawców. Właściciele firmy Breitkopf und Härtel mieli wpływ na podejmowane przez Polaka decyzje w sprawach wydawniczych.

W roku 1848 wydawnictwo i księgarnia usytuowane przy ulicy Petersstrasse stały się własnością Jana Nepomucena Bobrowicza.

Książki Księgarni Zagranicznej nie były treściowo związane z emigracja, były wydawnictwami dla przeciętnego odbiorcy, zwłaszcza dla dzieci. Wydawnictwa Bobrowicza cechowały: staranna, czasem zbytkowna szata graficzna i doskonały krój czcionek ${ }^{14}$. Wiele tytułów miało dwa wyda-

13 Ibidem, s. 52.

14 A. Banach, Polska ksiązka ilustrowana 1800-1900, Kraków 1959, s. 130-132. 
nia: zwykłe i luksusowe. Wydania luksusowe posiadały oprawy z płótna angielskiego, safianu czy skóry z wyciskami, zawierały więcej ilustracji niż edycje zwykłe. Większość edycji Bobrowicza należała jednak do tanich. Dominowały książki beletrystyczne oraz dzieła historyczne. Książki wchodzące w skład serii miały zawsze określony, jednakowy format, dla znacznej części Bobrowicz projektował dwie karty tytułowe. Większość tytułów była zaopatrzona w portrety ich autorów; Polak zwracał uwage na estetykę swoich druków. Nie zawsze wiązało się to z poprawnością tekstu. Błędy polegały przede wszystkim na opuszczaniu, przestawianiu lub nieprawidłowym wydrukowaniu liter, względnie całych wyrazów. Powstałe pomyłki były „zasługą" niemieckich zecerów nieznających przecież języka polskiego.

Librairie Étrangère była przedsiębiorstwem sortymentowo-nakładowym, zapewniającym zbyt książek wydanych własnym nakładem, jak też objętych sprzedażą komisową. Taka księgarnia miała wykonywać usługi dla księgarzy i osób prywatnych, a polski wydawca utrzymywał kontakty ze wszystkimi krajowymi i zagranicznymi oficynami.

Księgarnia zarabiała między innymi na rabatach ustalanych przy przyjmowaniu książek w komis, z czego niezadowoleni byli księgarze korzystający z usług Bobrowicza. Konkurencja była ogromna, a prawa rynku księgarskiego bezwzględne. Pojawiały się kłopoty ze zbytem wydawnictw. Bywały one spowodowane nie tylko brakiem zdolności handlowych księgarza, ale też często wygórowanymi żądaniami oraz brakiem znajomości zapotrzebowań czytelniczych osób dysponujących książkami. W handlu Bobrowicz kierował się słusznymi zasadami, nie potrafił jednak egzekwować należnych mu kwot. Lista dłużników, do których wysyłał monity z prośbą o zwrot należności, była długa. Mimo problemów z dłużnikami wydawca bezgranicznie ufał swoim klientom, zapewne nie żądał od nich pokwitowań za świadczone im usługi.

Według Słownika pracowników książki polskiej Nepomucen Bobrowicz nie był również zbyt solidny wobec autorów książek - nie zawsze dotrzymywał zobowiązań - dlatego też nie doszło do wydania Polskich wieków średnich Joachima Lelewela. Hanna Batorowska, autorka monografii o Bobrowiczu, inaczej przedstawia sprawę z Lelewelem. Bobrowicz, zdaniem autorki, pomagał w poszukiwaniu wydawców dzieł historyka. Twórcy biogramów Bobrowicza, jak Zofia Walczy czy Piotr Chmielowski, powoływali się głównie na incydent między Bobrowiczem a Lelewelem przy wspomnianym dziele. Polska wieków średnich, czyli w dziejach narodu polskiego postrzeżenia była projektowana przez Eustachego Januszkiewicza i Walentego Zwierkowskiego oraz Adama Wróblewskiego i Bobrowicza. Zadanie polskiego wydawcy miało 
ograniczać się do opublikowania tegoż dzieła. Lelewel miał wiele problemów z jego wydaniem. Zawiedli go współautorzy projektu, Józef Bohdan Zaleski i Antoni Czerniewski, którzy nie zdołali projektu doprowadzić do końca. Gdy w roku 1843 nie doszło do wydania dzieła, Lelewel znalazł się w trudnej sytuacji materialnej, dlatego też liczył na wynagrodzenie, które miało nadejść z Lipska. Bobrowicz ofiarował Lelewelowi 400 franków, lecz później, gdy historyk miał już przygotowane dzieło do druku, wydawca, bojąc się zbyt dużych kosztów, wycofał się z przedsięwzięcia. Lelewel w listach do Zwierkowskiego nazywał Bobrowicza „wielkim ladaco” i „podłym łotrem” ${ }^{15}$.

W opinii współczesnych Bobrowicz miał wykorzystywać pisarzy, których prace ogłaszał drukiem: „nie zawsze dotrzymywał zobowiązań wobec autorów [...] i płacił Bobrowicz autorom bardzo niskie honoraria; mógł więc, nie zważając na protesty rujnowanych wydawców krajowych, taniej od nich sprzedawać książki"16.

Brak umiejętności handlowych oraz silna konkurencja miejscowych potentatów wydawniczych, głównie Brockhausa, doprowadziły Bobrowicza w 1859 roku do bankructwa. Nakłady pozostałe po upadku księgarni wykupił Zygmunt Gerstmann, który od 1858 roku prowadził księgarnię polską w Brukseli. Wiadomo, iż sprzedawał książki Bobrowicza jako własne wydawnictwa.

W 1859 roku Jan Nepomucen udał się z rodziną do Drezna, gdzie zajmował się głównie działalnością księgarską. Prawdopodobnie w kwietniu lub maju tego roku założył $\mathrm{w}$ tym mieście filię Librairie Étrangère. Nie można jednak ustalić, jak długo funkcjonowała ta placówka, ponieważ nie zachowały się żadne - poza listami do Tadeusza Działyńskiego dokumenty świadczące o istnieniu księgarni ${ }^{17}$.

Niewątpliwie Bobrowicz w Dreźnie zajmował się księgarstwem, potwierdzały to księgi adresowe - jeszcze w 1869 roku zaliczany był do grupy zawodowej księgarzy. Dopiero od roku 1870 aż do śmierci wydawcy $\mathrm{w}$ adnotacjach przy jego nazwisku przestaje pojawiać się określenie „Buchhändler", a zastępuje je „Literat", co pozwala stwierdzić, iż parał się także pracą literacką.

Jan Nepomucen Bobrowicz zmarł 2 listopada 1881 roku. Pochowany został w Dreźnie, na Nowym Cmentarzu Katolickim usytuowanym przy Bremerstrasse. Nagrobek Bobrowicza przetrwał do 1925 roku, a później

${ }^{15}$ H. Batorowska, Jan Nepomucen Bobrowicz..., s. 124

${ }^{16}$ Z. Walczy, Bobrowicz Jan Nepomucen, w: Słownik pracowników książki polskiej, red. J. Treichel, Warszawa-Łódź 1972, s. 73-74.

${ }^{17}$ H. Batorowska, Jan Nepomucen Bobrowicz..., s. 136-143. 
miejsce to zostało opłacone przez inną rodzinę. W 1958 roku grób wydawcy przestał istnieć.

Na sylwetkę zmarłego wydawcy większą uwagę zwróciło lwowskie czasopismo „Szkoła. Tygodnik Pedagogiczny”, w którym zamieszczono informację o śmierci księgarza:

Dnia 2 listopada br ${ }^{18}$ zmarł w Dreźnie Jan Nep. Bobrowicz, księgarz. Śp. zmarły znany i poważany powszechnie jako człowiek prawego charakteru i wielki patriota był wydawcą wielu przedruków polskich [...]. Działalność ta tym więcej na uznanie zasługuje, iż podjęta była w $1.1830-1848$, a więc w chwili, w której zupełny zastój wydawnictwa dotkliwie w kraju czuć się dawał ${ }^{19}$.

Podanie dokładnej liczby tytułów, które wyszły z oficyny Bobrowicza, jest prawie niemożliwe. Brak jest spisów bibliograficznych sporządzonych przez wydawcę $\mathrm{w}$ całym okresie istnienia firmy. Ustalona liczba 135 wydawnictw opracowanych edytorsko przez Bobrowicza nie jest ostateczna, wydał on o wiele więcej tytułów, o czym świadczą informacje pochodzące $\mathrm{z}$ jego korespondencji ${ }^{20}$.

Oficyna polskiego wydawcy miała do zaoferowania swoim klientom ogółem 151 tytułów książek wydanych w Lipsku; dodając do tej liczby kolejne edycje, często poszerzone, uzyskamy 183 tytuły, którymi handlowała Librairie Étrangère.

Księgarnia dysponowała nie tylko drukami zwartymi, ale także czasopismami wydawanymi w Wilnie, Poznaniu czy Warszawie.

Nakładem Bobrowicza ukazała się „Biblioteka Powieści Historycznych” (1844-1856) oraz francusko-polska „Biblioteka Malownicza Najzabawniejszych Powieści dla Dzieci" (1846). Wydał również Kazania na niedziele Piotra Skargi, Biblię Jakuba Wujka, Rękopis znaleziony w Saragossie Jana Potockiego oraz Pod włoskim niebem Józefa Ignacego Kraszewskiego. Według Karola Estreichera ogłosił również Katalog ksiażek polskich wydanych własnym nakładem lub znajdujacych się w Ksiegarni Zagranicznej.

Skłoniwszy swych pracodawców, Breitkopfa i Härtla, do intensywniejszego wydawania książek polskich, przygotował dla nich między innymi 37 tomów serii „Biblioteka Kieszonkowa Klasyków Polskich”, dziesięciotomowy Herbarz polski Kaspra Niesieckiego, dwunastotomowe Dzieła poetyczne wierszem i proza Juliana Ursyna Niemcewicza czy książkę Napoleon Bonaparte, czyli obraz bitew i wydaną po paru latach powtórkę

\footnotetext{
181881 r. - przyp. aut.

${ }^{19}$ H. Batorowska, Jan Nepomucen Bobrowicz..., s. 154.

${ }^{20}$ Ibidem, s. 91.
} 
zatytułowaną Kroniki malownicze Napoleona. Przygotował wydanie Meliteli. Noworocznika na rok 1837, przedrukował także Życia sławnych Polaków według edycji Mostowskiego.

Polski księgarz, wydawca i edytor wydał ogółem 400 tomów dzieł polskich, z czego połowę we własnej firmie.

Jego działalność wydawnicza przyczyniała się do rozwoju kultury polskiej; cechowały ją: umiejętny dobór autorów, staranna szata edytorska, a także podejmowanie zbytkownych, z przepychem ilustrowanych wydawnictw ${ }^{21}$.

\section{Erazm Łukasz Kasprowicz}

Po ustąpieniu Jana Nepomucena Bobrowicza książką polską w Lipsku zajął się sam „król księgarstwa” - Brockhaus - słynny wydawca słowników. Firmę założył Friedrich Arnold Brockhaus, została ona przeniesiona z Amsterdamu do Lipska w roku 1817. Tam oprócz wydawnictwa założył również drukarnię. Obecnie wydawnictwo istnieje jako państwowe T.A.B. w Lipsku i pod tą samą nazwą firma prywatna w Wiedniu ${ }^{22}$.

Wiadomo, iż Brockhaus doskonale orientował się w środowisku emigracji polskiej, że pośredniczył w komisowym handlu oraz kolportażu książek polskich do kraju.

W listopadzie 1840 roku Brockhaus odwiedził Adama Mickiewicza; skutkiem spotkania było opublikowanie trzech tomików poety. W latach następnych firma podjęła poważne przedsięwzięcie wydawania książek polskich, zwłaszcza przedruków z pierwszych wydań francuskich. Za sprawą swojego młodszego, ale wysoko cenionego pracownika Erazma Łukasza Kasprowicza, redaktora i korektora książek polskich, Brockhaus wydawał w latach 1860-1886 zasłużoną serię „Biblioteka Pisarzy Polskich" 23 .

Erazm Łukasz Kasprowicz urodził się w maju 1835 roku w Zagórzu pod Częstochową. Ojciec, Kajetan, zmarł rok po narodzinach syna, matka, Salomea, osiem lat później; Erazma wychowywała rodzina matki. Nie chciał być ciężarem dla owdowiałej w tym czasie ciotki, mając więc niespełna 13 lat, zaczął praktykę w księgarni D.E. Friedleina w Krakowie, gdzie pracował do roku 1854. W tym też roku wyjechał do Lipska i objął posadę w księgarni wydawniczej prowadzonej przez Jana Nepomucena

\footnotetext{
${ }^{21}$ S.P. Koczorowski, op.cit., s. 158.

${ }^{22}$ Encyklopedia wiedzy..., s. 338.

${ }^{23}$ B. Zakrzewski, Dwaj wieszcze: Mickiewicz i Wernyhora, Wrocław 1996, s. 162-163.
} 
Bobrowicza. Tu pracował do momentu likwidacji w roku 1859. Wtedy przeszedł do znanej, wielkiej firmy wydawniczo-księgarskiej F.A. Brockhausa w Lipsku i rozpoczął pracę w charakterze pomocnika księgarskiego w dziale zagranicznym księgarni sortymentowej ${ }^{24}$.

Firma dosyć szybko podjęła pomysł Kasprowicza polegający na wydawaniu i sprzedawaniu na szeroką skalę książek w językach słowiańskich.

W roku 1860 zaczęła ukazywać się „Biblioteka Pisarzy Polskich” książki w formacie szesnastki, w oprawach płóciennych z emblematem patriotycznym i z podobną liczbą arkuszy w tomie. W drukarni wyszło 81 tomów „Biblioteki Pisarzy Polskich” (Kasprowicz we własnej drukarni wydał jeszcze dwa: 82. i zamykający serię 83. tom). Wśród nich wyróżnić należy kilkutomowe dzieła trzech wieszczów, pierwsze zbiorowe wydanie pism Norwida, prace Konstantego Gaszyńskiego, Agatona Gillera i wielu innych. Niewątpliwą zasługą Kasprowicza było to, że kierując serią, decydował w dużym stopniu o doborze autorów ${ }^{25}$.

Wszystkie pozycje były przygotowywane w specjalnie dla tego celu przystosowanym dziale drukarni Brockhausa. Wydano między innymi kilkutomowe dzieła Władysława Bełzy, Michała Czajkowskiego, Kornela Ujejskiego, Stanisława Witkiewicza (ojca Stanisława Ignacego Witkiewicza).

Kolekcja szybko znalazła czytelników i długo cieszyła się powodzeniem. Książki z serii, mimo że były niestaranne pod względem poprawności korektorskiej czy nawet redakcyjnej, docierały wszędzie tam, gdzie pojawiali się Polacy tułacze, wywołując entuzjazm. Do dziś „Biblioteka Pisarzy Polskich" jest poszukiwana i kompletowana przez biblioteki i bibliofilów ${ }^{26}$.

Kasprowicz opracowywał również miesięcznik „Bibliografia Polska. Wykaz wszelakich tworów literatury polskiej, wychodzącej w kraju i za granicą".

Wyruszył do Polski w 1863 roku, gdy dotarły do niego informacje o przygotowywaniu powstania styczniowego. Obserwowany przez policję pruska, następnie austriacką zmuszony był zatrzymać się w Galicji wschodniej, gdzie przez pewien czas pełnił obowiązki administratora majątku hrabiego Seweryna Uruskiego. Po upadku powstania Kasprowicz powrócił do Lipska i niemal natychmiast przystąpił do dalszej

${ }^{24}$ A. Krawczyński, Erazm Łukasz Kasprowicz - księgarz i wydawca (1835-1922), „Księgarz” 1964, nr 4, s. 46.

25 B. Zakrzewski, op.cit., s. 199.

${ }^{26}$ A. Krawczyński, op.cit., s. 47-48. 
pracy w firmie Brockhausa. W tym czasie utrzymywał rozległe kontakty z wieloma emigrantami, korzystał z rad i wskazówek Józefa Ignacego Kraszewskiego.

W oddziale zagranicznym księgarni sortymentowej Brockhausa zorganizowano centralę importu, ekspedycji i sprzedaży wszelkich książek w językach słowiańskich. Odtąd kupowano lub przyjmowano na skład w komis macierzyste wydawnictwa ukazujące się gdziekolwiek na emigracji. Już wkrótce centrala rozwinęła się, wzrosły obroty i powiększano zasięg odbiorców.

Brockhaus prowadził między innymi skład główny na zagranicę nakładów Gebethnera i Wolffa, także Henryka Natansona z Warszawy, Jana Konstantego Żupańskiego z Poznania, Wilda ze Lwowa.

Mimo tych finansowych sukcesów Kasprowicz wynagradzany był na poziomie średnich płac pomocnika księgarskiego. Pracował po osiem-dziewięć godzin dziennie, dodatkowo wykonywał inne zajęcia: korektorskie, redaktorskie, tłumacza sądowego, tłumaczenia z języka obcego dla instytucji ${ }^{27}$.

W lutym 1864 roku Kasprowicz rozesłał drukowany cyrkularz zawiadamiający świat księgarski, że otwiera własne przedsiębiorstwo księgarskie w Lipsku pod nazwą Slavische Buchhandlung na ulicy Querstrasse ${ }^{28}$.

Początkowo firma działała jako wydawnictwo, natomiast od stycznia 1865 roku również jako księgarnia sortymentowa i antykwariat.

Erazm Kasprowicz tłoczył głównie druki polityczne, których nie chciał wydawać Brockhaus; należały do nich m.in.: Bard Oswobodzonej Polski, przeznaczony szczególnie dla młodzieży, tom pierwszy Kapitału Karola Marksa drukowanego w Weimarze (pierwszy przekład polski; 1884), także Emigracja polska od r. 1831-1863. Krótki rys historyczny Wiktora Heltmana (1865), czy też Myśli o naszych działaniach w kraju i za granica Mateusza Gralewskiego (1865). Należy wspomnieć również o takim dziele jak List otwarty do teraźniejszego Towarzystwa Demokratycznego Jana Nepomucena Janowskiego (1867) ${ }^{29}$.

Katalog wydawnictw, uzupełniany ręcznie dopisywanymi tytułami, według stanu z połowy 1913 roku podaje 57 tytułów polskich, a wśród nich książki historyczne, pedagogiczne, monografie, broszurki (w szczególności emigracyjne), druki ulotne, kilka drobnych powieści, modlitewniki (m.in. w serii „Biblioteczka Nabożeństw Katolickich”, t. 1-6, 1866-1905), broszury dewocyjne, popularne podręczniki gospodarstwa wiejskiego.

\footnotetext{
${ }^{27}$ Ibidem.

28 A. Kłossowski, Polscy księgarze i wydawcy..., s. 158-161.

${ }^{29}$ Z. Walczy, Kasprowicz Erazm Łukasz, w: Słownik pracowników..., s. 400.
} 
W języku ukraińskim Kasprowicz wydał oprócz powieści w formie kieszonkowej zbiór poezji i pieśni ludowych, natomiast w języku rosyjskim 36 tomów z kolekcji „Mezdunarodnaja Biblioteka”, w tym przeważnie utwory literackie i o treści politycznej (1871-1909), zbiory poezji, a także niedozwolone w Rosji utwory Lermontowa, Puszkina i Rylejewa.

Nakłady Kasprowicza, drukowane głównie u lipskiego nakładcy, miały skromną szatę graficzną, były tanie i popularne wśród emigracji polskiej za granicą oraz w kraju. Kasprowicz rozprowadzał te książki za pomocą kilku księgarń w Polsce, zmuszony był korzystać z usług przypadkowych sprzedawców uprawiających handel obnośny. Wiązało się to z ryzykiem niewypłacalności, nieuchwytności, co narażało księgarza na straty.

Mimo tych problemów 1 stycznia 1865 roku Kasprowicz rozesłał nowy, tym razem obszerniejszy drukowany cyrkularz, uwzględniający zwłaszcza książki w językach słowiańskich i o tematyce dotyczącej tych krajów ${ }^{30}$.

Ciekawe, iż w postscriptum cyrkularza pojawiła się rekomendacja firmy F.A. Brockhausa, w której Kasprowicz pełnił nadal obowiązki pracownika: „biorąc pod uwagę przyjacielskie i handlowe wzajemne stosunki [...] polegać one będą $\mathrm{w}$ dalszym ciągu na uzupełnianiu się, szczególnie w zakresie literatury slawistycznej" ${ }^{31}$. To nietypowa sytuacja, wiadomo bowiem, że w Niemczech ustawowo było niedozwolone prowadzenie przedsięwzięć finansowych na własny rachunek pracownikom najemnym w zakresie tej samej branży. To oświadczenie wskazuje, że firma lipska ceniła sobie współpracę z Polakiem.

Wyjątkowa życzliwość potężnego koncernu Brockhausa pozwoliła Kasprowiczowi utrzymać się przy księgarni przez długie lata, aż do jego śmierci, mimo zaangażowania się $\mathrm{w}$ edycje wielu zakazanych $\mathrm{w}$ kraju dzieł, niewypłacalności niektórych kontrahentów oraz stosunkowo małych kapitałów obrotowych. Wielce prawdopodobne jest, iż Brockhaus nie działał bezinteresownie. Formalnie całkowicie samodzielna księgarnia Kasprowicza mogła stanowić dla niego dogodną zasłonę dla własnych wydawnictw, które choć opłacalne, były niewygodne, szczególnie ze względów politycznych.

W latach 1875 oraz 1881 Kasprowicz ogłosił broszurkę Das slavische Kommissionshaus in Leipzig, projekt stworzenia w Lipsku centrali handlu książką opartej na kapitale polskim, mającej zastąpić pośrednictwo niemieckie między Słowiańszczyzną a Zachodem. Przedsięwzięcie to mimo

\footnotetext{
${ }^{30}$ A. Krawczyński, op.cit., s. 48.

${ }^{31}$ Ibidem.
} 
przychylnej opinii historyka Józefa Kazimierza Plebańskiego czy Józefa Ignacego Kraszewskiego nie zostało zrealizowane ${ }^{32}$.

W roku 1909 po ciężkiej operacji Kasprowicz przestał pracować dla Brockhausa - został zwolniony z obowiązków i otrzymał dożywotnio pełne uposażenie, takie, jakie do tej pory pobierał.

Łącznie, z przerwą w okresie powstania styczniowego, Kasprowicz przepracował w niemieckiej firmie około 50 lat. Księgarz „na emeryturze” zajął się rozprowadzaniem własnych wydawnictw, pisaniem artykułów do prasy emigracyjnej, służeniem radą coraz to nowym wydawnictwom emigracyjnym ${ }^{33}$.

Działalność firmy przerwała śmierć Erazma Łukasza Kasprowicza 22 listopada 1922 roku. W roku 1923 przeprowadzono likwidację firmy; wydawnictwa zakupiła firma W. Ładyżnikowa w Berlinie.

Erazm Łukasz Kasprowicz, księgarz i wydawca polski na obczyźnie, pracowitym życiem i wiernością dla zawodu przysłużył się krajowi i kulturze polskiej, a jego księgarnia była ośrodkiem polskiego życia kulturalnego na obczyźnie. Należała do nielicznych w tym okresie polskich księgarń i wydawnictw, których działalność nie zakończyła się bankructwem.

\section{Paweł Rhode}

Ambicje współzawodnictwa z potentatami lipskimi kończyły się zwykle niepowodzeniem. Przekonało się o tym wielu księgarzy i wydawców. Jednym z nich był wspomniany Jan Nepomucen Bobrowicz, drugim inny Polak - Paweł Rhode.

Natura obdarzyła Rhodego spokojnym charakterem, taktem i subtelnością. Nawet oczywistych racji nie chciał dochodzić ostrymi interwencjami lub procesami, wolał pogodzić się ze stratami ${ }^{34}$.

Odebrał wykształcenie zupełnie wówczas wystarczające do zajmowania się sprawami wydawniczymi i księgarskimi. Nie wiadomo, dlaczego osiadł na obczyźnie, ale pewne jest, iż nie była mu obojętna sprawa polska oraz troska o rozwój i upowszechnianie w świecie kultury i literatury ojczyzny ujarzmionej przez zaborców.

Praktykę odbył pewnie u Brockhausa. Własne przedsiębiorstwo księgarsko-wydawnicze założył na przełomie lat 1864 i 1865. Mieściło się ono nieopodal księgarni Kasprowicza, na ulicy Querstrasse. Firma nazywała

\footnotetext{
${ }^{32}$ Z. Walczy, Kasprowicz Erazm Łukasz, s. 400.

33 A. Krawczyński, op.cit., s. 48.

${ }^{34}$ A. Kłossowski, Polscy księgarze i wydawcy..., s. 162.
} 
się: Paul Rhode. Verlags-Buchhandlung. Używano też innych nazw: Księgarnia Pawła Rhode lub Paweł Rhode, a na drukach niemieckich - Verlag von Paul Rhode ${ }^{35}$.

Rhode wielokrotnie silnie podkreślał polski charakter swojej firmy, oświadczając, że jest rzeczą „niepotrzebna, by niemieckie domy [...] wszystkim co polskie się zajmowały" ${ }^{\prime \prime}$. Polak starał się przynieść pożytek sprawie polskiej, przyczynić się do podtrzymania i rozwoju narodowej literatury i kultury, przybliżenia jej światu.

Takie pojmowanie roli księgarza polskiego na obczyźnie zapewniło mu życzliwą opiekę Józefa Ignacego Kraszewskiego. To z nim Rhode konsultował ważne zamierzenia, korzystał z jego pośrednictwa w nawiązywaniu stosunków z innymi księgarzami i autorami, także przy odbieraniu i ekspediowaniu przesyłek z książkami. Rady pisarza przyjmował bezkrytycznie, a wszelkie jego życzenia wypełniał ze skrupulatnością i w zadziwiającym pośpiechu.

Rhode 15 października 1867 roku pisał:

Jeśli te książki, które Panie pragniesz mieć, zapiszesz ode mnie, dam tak, jak będę miał od antykwarzy jako księgarz, tj. z 10 lub 15\% i bardzo upraszam zdać na mnie miły mi obowiązek, móc w czemkolwiek Panu przysłużyć i oszczędzać czasu obstalunków pojedynczych ${ }^{37}$.

Będąc człowiekiem uczciwym, lojalnym wobec swoich kontrahentów i współpracowników, lecz niezbyt majętnym, nigdy nie rozbudował księgarni do większych rozmiarów. W roku 1866 podjął się przygotowania największego i najgłośniejszego przedsięwzięcia edytorskiego - niemieckiej gazety muzycznej i teatralnej „Neue Allgemeine Zeitschrift für Theater und Musik". Zapowiedź tego czasopisma przyjęto entuzjastycznie. Rhode zamierzał pismo poświęcić w dużej mierze zagadnieniom muzyki i sztuki w Polsce. Prosił Kraszewskiego o opiekę nad nim oraz pomoc w wyszukaniu stałych korespondentów, szczególnie z Polski ${ }^{38}$.

Redaktorem gazety został Jurij Karłowicz Arnold, rosyjski kompozytor i pedagog. Pierwszy numer ukazał się 10 stycznia 1867 roku, został przychylnie przyjęty przez krytykę. „Neue Allgemeine Zeitschrift

${ }^{35}$ Ibidem, s. 163.

${ }^{36}$ Z listu do Kraszewskiego, cyt. za: A. Kłossowski, Na obczyźnie..., s. 113.

37 Z listu z 15 października 1867 roku, Korespondencja Kraszewskiego, Biblioteka Uniwersytetu Jagiellońskiego, Czytelnia Zbiorów Audiowizualnych, mns. 6528, fol. 375.

${ }^{38}$ Z listu z 23 października 1866 roku, Korespondencja Kraszewskiego, Biblioteka Uniwersytetu Jagiellońskiego, fol. 360-361. 
für Theater und Musik" ukazywała się do 1868 roku, wzbogacając fachowe piśmiennictwo teatralne obszernymi rozprawami.

Rok 1867 przyniósł kolejny sukces wydawniczy. Było nim trzytomowe dzieło Jurija Arnolda (redaktora wspomnianej gazety) o przedstawieniach operowych $^{39}$. Złożyło się na nie 12 wychodzących co miesiąc zeszytów, ozdobionych 120 drzeworytami. Już pierwszy cyrkularz miał 300 prenumeratorów Operncharaktere ${ }^{40}$ !

Nadto Rhode ogłosił w 1867 roku kilka książek - m.in. Juliusza Rogera Album polonischer Volklieder der Oberschleiser przetłumaczony z języka polskiego przez Alberta Weissa oraz Historię reform politycznych w dawnej Polsce Karola Boromeusza Hoffmana i Horacjusza ody, satyry i listy w przekładzie Juliana Ursyna Niemcewicza. Przyjął również w komis dwie prace Zygmunta Gutta ukrywającego się pod pseudonimem Bolesław Świerszcz: Napoleon III. Terytorialne wynagrodzenia Francji oraz Prasa polska $i$ sentymentalizm polityczny ${ }^{41}$.

W 1868 roku najważniejszym wydawnictwem księgarni były sześciotomowe dzieła zebrane Karoliny Wojnarowskiej, którymi zapoczątkowano tanią serię wydawniczą zatytułowaną "Biblioteka Domowa Polska”. Pomysł utworzenia tej serii wypływał z hasła pracy organicznej, które sprzyjało powstawaniu wydawnictw służących rozwojowi oświaty i podnoszeniu kultury umysłowej społeczeństwa. W latach 60 . rozwijały się więc popularne, tanie serie wydawnicze, m.in. „Biblioteka Pisarzy Polskich" Brockhausa w Lipsku. Rhode z jednej strony chciał konkurować z ukazującą się „Biblioteką Domową”, a z drugiej - oddawać w ręce publiczności dzieła „najstosowniejsze względem obecnego położenia Polski" ${ }^{42}$. Pewnie za radą Kraszewskiego omawiana seria otrzymała nazwę „Biblioteka Domowa Polska”. Na kartach tytułowych jej pierwszych tomów Rhode położył sygnet złożony z kompozycji wizerunku drzewa, własnych inicjałów oraz szarfy z hasłem turbine crescit („,burzą rośnie”).

Działalność księgarza ustała po wydaniu kilku książek Karoliny Wojnarowskiej. Wydawca zapoczątkował nimi, a zarazem - na skutek likwidacji firmy w 1868 roku - zakończył tanią serię wydawniczą „Biblioteka Domowa Polska" 43 .

${ }^{39}$ Vierundzwanzig Operncharaktere in Bezug auf deren musikalisch-declamatorische wie dramatisch-mimische Darstellung.

40 A. Kłossowski, Polscy księgarze i wydawcy..., s. 167.

${ }^{41}$ Ibidem, s. 168.

${ }^{42}$ Z listu z 25 października 1867 roku, Korespondencja Kraszewskiego, Biblioteka Uniwersytetu Jagiellońskiego, mns. 6528, fol. 371-372.

43 A. Kłossowski, Na obczyźnie..., s. 120. 
Z wyjątkiem jednego wszystkie znane $\mathrm{z}$ autopsji wydawnictwa Rhodego drukowane były u A.Th. Engelhardta w Lipsku, zwanego przez księgarza „swoim drukarzem”. Książki Rhodego nie odbiegały jakością i zewnętrznym wystrojem od przeciętnych książek tego okresu. Oprawiano je w cienki karton lub gruby papier, część egzemplarzy miała sztywne, ozdobne okładki, oczywiście za wyższą cenę.

Rhode był nie tylko wydawca, ale i księgarzem. Wszystkie wydawnictwa, które posiadał do sprzedaży, były stosunkowo nowe. Opuściły prasy drukarskie $\mathrm{w}$ ostatnim dwudziestoleciu. $\mathrm{W}$ ofercie miał przede wszystkim 1000 poloników, w tym poezję i prozę literacką autorów polskich, dzieła muzyczno-teatralne. Rozpiętość cen książek i innych artykułów była znaczna i uzależniona od wielu czynników, ale u Rhodego można było przebierać $\mathrm{w}$ popularnych $\mathrm{w}$ drugiej połowie XIX wieku wariantach tego samego wydania. W zależności od oprawy, gatunku papieru czy ilustracji ceny wahały się w granicach $25-50 \%$ wartości najdroższego egzemplarza danej książki ${ }^{44}$.

Podjęte przez Rhodego w roku 1867 wydawnictwo „Neue Allgemeine Zeitschrift für Theater und Musik" okazało się przedsięwzięciem udanym, lecz przedwczesnym. Dla Rhodego związana z nim strata 3000 talarów oznaczała pozbycie się całego kapitału obrotowego.

Rok później wydawca szukał wspólnika, jednak bez rezultatu. Został wywłaszczony z księgarni, powołano tymczasowego zarządcę i likwidatora firmy. Nie wiadomo dokładnie, co spotkało księgarnię Rhodego, zapewne została wystawiona na licytację. Razem z nią znikł sam Paweł Rhode; dalsze jego losy są nieznane ${ }^{45}$.

\section{Zakończenie}

W XIX i na początku XX wieku czynnikiem sprawczym produkcji i dystrybucji książki polskiej na obczyźnie były kolejne fale emigracji polskiej, przymusowej lub dobrowolnej ${ }^{46}$.

Od roku 1833 nie było dnia, w którym na obczyźnie nie ukazywałaby się polska książka i gazeta, w którym poza krajem nie działałoby polskie wydawnictwo. Rzuceni za granicę Polacy zakładali obce, profesjonalne firmy antykwaryczne, drukarskie czy wydawnicze bądź stawali na ich czele. Nie wszystkim udało się wytrwać w nowych warunkach. Tak było

\footnotetext{
44 A. Kłossowski, Polscy księgarze i wydawcy..., s. 175.

45 Ibidem, s. 181.

${ }^{46}$ H. Szwejkowska, op.cit., s. 115.
} 
z Adamem Chłędowskim, uczestnikiem powstania listopadowego, który na próbie prowadzenia w Paryżu księgarni francusko-niemieckiej stracił wzrok i majątek. W długi popadł Stanisław Kraków, który pod koniec XIX wieku założył w Paryżu nowocześnie wyposażoną drukarnię fototypiczną. Jest oczywiste, iż w prawie wszystkich tego typu firmach polska książka cieszyła się specjalnymi względami ${ }^{47}$.

Trudno podać w przybliżeniu liczbę placówek, które zajmowały się promocją książki polskiej wśród emigracji. Jeszcze trudniej określić, ilu Polaków związało swą działalność zawodową z profesją emigracyjnego wydawcy, księgarza czy drukarza. Pewne jest natomiast, że wszyscy obierający zawód księgarza lub wydawcy musieli liczyć się z koniecznością pokonywania barier. Szczególnie niekorzystnie przedstawiało się ich położenie, gdy Polskę wymazano z mapy Europy. Na przykład rząd francuski, nie chcąc narażać się na kłopotliwe interwencje Rosji, bacznie śledził poczynania polskich emigrantów ${ }^{48}$.

Czas trwania firm księgarsko-wydawniczych, ich rozmiary, zakres działalności, profil i zasięg oddziaływania były zróżnicowane i uzależnione od wielu czynników. Można do nich zaliczyć: wysokość kapitału zakładowego, kwalifikacje zawodowe, zmysł ekonomiczny i zaangażowanie właścicieli. Ważne były także: poziom kulturalny, przygotowanie czytelnicze oraz - bardzo istotne - zaangażowanie w sprawy narodowe miejscowych środowisk emigracyjnych i organizacji czy instytucji krajowych $^{49}$. Stanowisko wydawców krajowych traktujących książkę przede wszystkim jako towar, za który żądali zbyt wysokiej ceny, sprawiło, że aż do lat międzywojennych wydawnictwa ich napływały za granicę skromnie. Żadna z firm polskich na obczyźnie nie mogła też liczyć na większą pomoc ze strony kraju. Słabo rozwijała się współpraca z żądnymi zysku krajowymi księgarzami. Płynna klientela oraz często trudne warunki pracy pogłębiały niezwykle ciężką i specyficzną sytuację, w jakiej przyszło działać większości polonijnych księgarń i drukarń.

Stan emigracyjnego ruchu wydawniczego, księgarskiego czy drukarskiego na wychodźstwie był swego rodzaju zwierciadłem odbijającym zainteresowanie światowej opinii publicznej kwestią polską. Nie jest dziełem przypadku, że największy rozkwit księgarstwa i drukarstwa na obczyźnie nastapił w latach 30. XIX wieku i wiązał się z rolą i znaczeniem Wielkiej Emigracji. W latach 50. tego stulecia instytucje ledwo wegetowały, by rozwinąć się na nowo bezpośrednio przed powstaniem

\footnotetext{
47 A. Kłossowski, Na obczyźnie..., s. 45-46.

48 Ibidem, s. 49-50.

49 A. Kłossowski, Polskie oficyny wydawnicze na obczyźnie, Warszawa 1993.
} 
styczniowym 1863 roku i po nim ${ }^{50}$. Wielka fala emigracji zarobkowej w latach 70. XIX wieku, która zaczęła podążać za ocean, a później do Niemiec i Francji, spowodowała kolejne odrodzenie księgarstwa i drukarstwa polskiego w krajach europejskich. Zaspokojenie potrzeb czytelniczych emigracji zarobkowej legło również u podstaw zakładanych już w XX wieku wyspecjalizowanych polskich oficyn wydawniczo-księgarskich.

Większość zesłańców i tułaczy żywiła głęboką nadzieję, że rozłąka z ojczyzną nie potrwa długo. Rzeczywistość jednak często była okrutna. Wielu rodaków ujrzało ziemię ojczystą dopiero na starość, inni pozostali na emigracji do końca swego życia. Niektórzy z nich wiedzieli, że będzie im dane spędzić za granicą wiele lat. Dlatego też głównym narzędziem walki ideowej i obrony przed otaczającą obcością były druki polskie wydawane na obczyźnie. Do tych tułaczy zaliczymy niewątpliwie zaprezentowanych w niniejszym artykule: Bobrowicza, Kasprowicza oraz Rhodego. Na ich barkach spoczywały niesłychanie trudne i odpowiedzialne zadania, które w normalnych warunkach byłyby przedmiotem działania poważnych instytucji narodowych lub społecznych. Obowiązki te księgarze i wydawcy podjęli i w większości wywiązali się z nich wzorowo. Najważniejsze, iż odcięci od ojczyzny nigdy nie zapomnieli o tym, że są Polakami, że nie dali zapomnieć o tym rodakom rzuconym w wir emigracyjnych losów na całym świecie.

\author{
AGNIESZKA ŁUKOMSKA-KRYGER
}

\title{
Polish emigre publishing and book trade in Leipzig between 1830-1918
}

\begin{abstract}
Aвstract. This article attempts to summarize and systematize available data on Polish emigre publishing, printing and book trade in Leipzig. The chronological span covers the years 1830-1918, i.e., shortly before the outbreak of the November insurrection, the following years of the emigration of political elites from Poland (the socalled Great Emigration) until the times when Poland regained its independence in 1918.
\end{abstract}

Key words: Great Polish political Emigration, publishing and book trade, Leipzig, Jan Nepomucen Bobrowicz, Erazm Ł. Kasprowicz, Paweł Rhode.

${ }^{50}$ A. Kłossowski, Na obczyźnie..., s. 35. 
